\title{
A “NOITE ESCURA DA ALMA" NO LABIRINTO DO SER POÉTICO
}

\section{THE “SOUL'S DARK NIGHT" IN THE LABYRINTH OF THE POETIC BEING}

\author{
Pe. Antoniel Batista dos Santos ${ }^{1}$ \\ Maria Goretti Ribeiro ${ }^{2}$
}

\begin{abstract}
Resumo: Interpretamos a metáfora "noite escura da alma", construída pelo poeta místico espanhol São João da Cruz, no poema Noche oscura, estabelecendo uma analogia com o processo de individuação teorizado por Jung. Tomando a imagem do labirinto como símbolo do difícil e obscuro caminho da psique, no tempo da revisão dos erros existenciais, analisaremos a trajetória da alma/anima em busca do deus transcendente/Self, evidenciando os arquétipos Anima/Eros, Self, proeminentes no poema em virtude do motivo da busca, para a realização do hierosgamos/sizígia da alma com o Amado.
\end{abstract}

Palavras-chave: Poesia; Processo de individuação; Labirinto simbólico.

Summary: We interpret the metaphor "soul's dark night", built by the Spanish mystic poet São João da Cruz in the poem 'Noche oscura', establishing an analogy with the process of individuation theorized by Jung. Taking the labyrinth image as a symbol of the difficult and obscure path of psyche, in the period of revision of existential errors, we will analyze the soul's/anima's trajectory in the search for the transcendent (Self) god, emphasizing the archetypes of anima/Eros, Self, prominent in the poem due to the search motif, for the accomplishment of the hierosgamos/sizigia of the soul with its Beloved one.

Keywords: Poetry; Individuation process; Symbolic labyrinth.

\footnotetext{
${ }^{1}$ Graduado em Filosofia pela Faculdade João Calvino, Barreiras - BA (2011) e em Teologia pela Universidade Católica de Pernambuco - UNICAP (2015). Especialista em Educação de jovens e adultos com ênfase em Economia Solidária pela Universidade Federal da Campina Grande (2018) e especialista em Filosofia e Sociologia pela Universidade Cândido Mendes (2018). Mestre em Teologia pela Pontifícia Universidade Lateranense ROMA, Itália (2013). Tema da Dissertação: “A Sacramentalidade da Palavra da Dei Verbum a Verbum Domini.". Professor de teologia no Centro de Estudos de Filosofia e Teologia (Seminário Diocesano de Campina Grande).

${ }^{2}$ Doutora em Letras e Linguística na Universidade Federal de Alagoas (2003), PósDoutora em Estudos Literários na Universidade Federal de Uberlândia (2017). Atua no Programa em Literatura e Interculturalidade da Universidade Estadual da Paraíba. Pesquisa sobre imaginário mítico-simbólico e arquétipos na literatura, nas artes e na cultura e sobre literatura. Presidente do Centro Paraibano de Estudos do Imaginário - CEPESI. É sócia fundadora do Centro Campinense de Estudos africanos. Membro do GT Imaginário, representações literárias e deslocamentos culturais, da ANPOLL. Coordena o Grupo de Estudos Junguianos AION na Universidade Estadual da Paraíba. Publicações, dentre outras: A via crucis da alma: leitura mitopsicológica da trajetória da heroína de As parceiras, de Lya Luft (2006), Imaginário da Serpente de A a Z (2016), Luz do Claustro - poesias (2017).
} 


\section{No princípio, o Amor...}

Como uma corça suspira pelas correntes das águas,

Assim a minha alma suspira por ti, ó Deus.

A minha alma tem sede de Deus, do Deus vivo; Quando virei e comparecerei diante de Deus?

(Salmos 42,1, 2)

NOCHE OSCURA 3 é um dos poemas que compõem a coletânea "Noche oscura", escrito pelo poeta espanhol São João da Cruz. Sua obra poética não ocupa mais de 40 páginas. Damos conta de mais duas coletâneas intituladas "Cántico Espiritual" e "LLama de amor viva".

Juan de Yepes nasceu em Ávila, no ano de 1542. Em 1563 ingressou no Convento carmelita de Santa Ana. De 1564 a 1568 frequentou a Universidade de Salamanca. Em 1577 passou a ser chamado de Fray Juãn de la Cruz. Por pretender reformar o Carmelo para imprimir à ordem a pureza de sua regra primitiva, foi preso no dia 2 de dezembro de 1577 por ordem do vigário-geral dos carmelitas e levado secretamente para Toledo onde permaneceu por vários meses em condições duríssimas numa masmorra escura. Mesmo privado de luz, o frade poeta escrevia em papel que o carcereiro lhe dava em sigilo os poemas que compusera mentalmente e fixara na memória. Quando fugiu do cárcere, em agosto de 1578, trazia escritas 31 estrofes do "Cántico Espiritual".

A obra que analisamos neste trabalho não reflete o mundo impiedoso de torturas, calúnias, fome, dificuldades de toda ordem por que passou São João da Cruz na prisão, em Toledo. Ao contrário, composta com abundante inteligência mística, ousadia das imagens, recursos simbólicos de extraordinária força, emoção profunda, grande conhecimento da Bíblia, a poesia de São João da Cruz, tão humana quanto contemplativa, transmite o mistério do Amor a Deus que não se desvela na sua substância e que apenas podemos intuir.

\footnotetext{
${ }^{3}$ Mantivemos a língua original em que foi escrito o poema para melhor sentir a poesia que emana dos versos na sua constituição fônico-melódica. A tradução do poema para língua portuguesa está anexa ao fim do artigo.
} 


\section{NOCHE OSCURA}

Canciones de el alma que goza

De habber llegado al alto estado de la perfeccion,

Que es la unión con Dios,

Por el camino de la negación espiritual

En una noche oscura,

Com ansias, en amores inflamada,

¡oh dichosa ventura!,

Salí sin ser notada,

Estando ya mi casa sosegada.

Ascuras y segura

Por la secreta escala, disfrazada,

¡oh dichosa ventura!,

A escuras y en coberta,

Estando ya mi casa sosegada

En la noche dichosa,

En secreto, que nadie me veía,

Ni yo miraba cosa,

Sin otra luz y guía

Sino la que en el corazón ardía

Aquesta me guiaba

Más cierto que la luz del mediodia

Adonde me esperaba

Quien yo bien me sabía,

En parte donde nadie parecía.

¡Oh noche, que guiaste!

¡Oh noche, amable más que el alborada!

¡Oh noche que juntaste

Amado con amada, 
Amada em el Amado transformada!

En mi pecho florido, Que enterro para él solo se guardaba,

Allí quedó dormindo,

$Y$ yo le regalaba,

Y el ventalle de cedros aire dava.

El aire del amena,

Cuando sus cabellos esparcía,

Con su mano serena

En mi cuello hería,

$Y$ todos mis sentidos suspendia.

Quedéme y olvidéme,

El rostro recline sobre el Amado;

Cesó todo, y dexéme,

Dexando mi cuidado

Entre las azucenas olvidado.

Inicialmente é mister comentar que o poema Noche oscura, que tematiza a ânsia da alma para encontrar o Amor divino, lembra o mito de Eros e Psiqué. Eros, o belo deus das origens mais remotas (do verbo grego erasthai, que significa "comprazer-se", "deleitar-se com o desejo ardente incoercível dos sentidos"), é o amor personificado; Psiqué, a bela mortal que vagou nos labirintos do inferno para conseguir o amor desse deus (do verbo grego psykhe, que significa "soprar", "respirar", "princípio vital”) é a alma personificada. A psicologia junguiana concebe Eros e Psiqué como arquétipos da conjunção amorosa transformadora e deles se apropria para explicar o processo de crescimento psico/espiritual.

O amor erótico por Deus é a chave com que abrimos acesso à metafórica travessia da alma pela noite escura no labirinto interior, no poema Noche oscura. Para além do sentido reducionista que os tempos modernos atribuem ao Eros, - tensão que provoca a prática sexual - o poema de São João da Cruz refere-se a um amor erótico místico e ressignifica este emprego convencional do termo quando sugere o sentimento de pertença ao Amado com ânsia de 
perenidade afetiva, alimentado pela certeza da fidelidade, da perfeita completude e da eterna felicidade.

No mito, a belíssima Psiqué, condenada às núpcias da morte pelo oráculo de Apolo, torna-se a esposa amada do deus escondido, que lhe ofereceu todo o deleite que uma mortal jamais imaginou receber. Mas, persuadida pelas leis nefastas do mundo concupiscente das invejosas irmãs, Psiqué perde Eros e tem que se submeter ao poder da sogra, Afrodite, que lhe impõe quatro inexecutáveis tarefas probatórias para reencontrar o amado. A última tarefa foi de descer às trevas labirínticas do mundo inferior para buscar a beleza que pertencia à deusa do Hades; em outras palavras, foi imputada a Psiqué a missão de conseguir trazer do mundo inferior a perfeição, tarefa que ela não conseguiu executar porque cometeu o grave erro de abrir a caixa proibida. E do Hades não teria saído se não fosse pelo auxílio direto do próprio deus que, por amá-la incondicionalmente, a resgatou do sono da morte.

Jung entendeu que a fase mais elevada de confrontação das realidades psíquicas é iniciada pelo Eros: no homem através da anima; na mulher, através do animus e do Eros, este tomado como o elemento complementar, uma vez que o consciente é caracterizado mais pela vinculação ao Eros do que pelo caráter cognitivo do logos. Fortes e enigmáticas são as energias eróticas que despertam a receptividade, a sensibilidade, a eloquência, a sabedoria, o dom da profecia, a euforia da criação, a sensibilidade à natureza e a capacidade de amar. Eros implica entrelaçamento amoroso, necessidade de uma relação profunda com o Outro, de envolvimento emocional totalizante, de compromisso e vínculo afetivo. Eros é a capacidade de viver e de se apaixonar, de abraçar o lado Sombra da personalidade, de alargar o campo da consciência e da percepção, de declinar para abstrações e ideologias. Eros revela o fascínio pela beleza, pela perfeição e proporciona o impulso à ação transformadora. (JUNG, 1988, p. 12).

Harding (1985, 58-64) considera o Eros um princípio espiritual, uma força anímica determinante em grandes atitudes humanas. Consciente na mulher e inconsciente no homem, esse arquétipo estimula o ser humano para a espiritualidade, para o cultivo da inteligência emocional, para o desenvolvimento da sensibilidade, para intuição das formas não concretizadas ou irrealizadas e para o favorecimento de uma abertura especial ao inconsciente. "Estar relacionado com o Eros significa estar orientado para aquilo que transcende ambições e objetivos pessoais", alcançando-se, através dele, uma relação transpessoal, uma vez que, submisso a esse arquétipo, o indivíduo pode ser redimido de uma orientação egoica, atingindo aquilo que está para além do desejo de poder. 


\section{Desvelando a alma}

A epígrafe do poema Noche oscura esclarece de quem é a voz que narra no texto poético: "Canciones de el alma que goza/ De habber llegado al alto estado de la perfeccion,/ Que es la unión con Dios,/ Por el camino de la negación espiritual”. Trata-se da alma. Mas quem é a alma que se rejubila de sua (a)ventura ao sair à noite escura, ardendo de amor, para encontrar o Amado?

Para os cristãos, a alma é o princípio espiritual do homem. "O relato bíblico exprime esta realidade com uma linguagem simbólica, ao afirmar que o Senhor Deus modelou o homem com argila do solo, insuflou em suas narinas um hálito de vida e o homem se tornou um ser vivente", criando, assim, uma unidade profunda entre alma e corpo (CIC, 1999, p. 104-105). A alma espiritual é semelhante a Deus, essência imaterial, etérea, invisível, imortal, que vinda do Criador, dá vida ao corpo e volta para Ele depois da morte.

Para o filósofo grego Sócrates, um dos maiores desafios do homem é conhecer a própria alma. Platão (2000, §611b-c), que vislumbrava a alma como essência pura, argumenta que para sabermos o que é a alma, será preciso contemplá-la não deformada pela união com o corpo e com tantas misérias, mas como ela é em si mesma. Pensando o Uno como o Bem supremo, a perfeição, condição transcendental do conhecimento que resplandece no mundo visível da matéria, Platão admite que a alma procede do Uno, uma fonte de bondade de onde se originam todas as coisas. O Bem, raio de luz que ilumina o mundo inteligível, em sua primeira hipóstase, reflete o esplendor do divino; em sua segunda hipóstase, reflete a alma, que está abaixo da inteligência e que seria o princípio motor, autora de movimento, razão existencial, semente de todo gênero da vida, sempre desejando alcançar o Bem supremo. Todavia, para alcançar o Bem, é preciso purificar os sentidos e refrear os instintos para se educar a sensibilidade, isto pelo impulso dinâmico do Amor que, segundo este filósofo, no Banquete (1973, p. 256 §208 a-e), tem capacidade de refazer o voo até a divindade, de libertar a alma das cadeias da matéria para elevá-la ao espírito.

Para Platão, a alma está sempre em luta com a matéria. Tal conflito se instaura quando, conectando-se com a natureza, hipóstase inferior, este princípio material de dispersão irracional turva o conhecimento, anuvia a inteligência, polui a ideia, profana a beleza. A luta perpétua e 
agônica da alma com a matéria sensível e instintual se produz no homem de forma violenta e relevante, conferindo a esta metafísica seu caráter profundo e dramático.

Para Jung, a alma não é baseada na matéria-mente-intelecto ou na metafísica, mas numa terceira realidade, que está entre a mente e o intelecto e promove dimensão criativa, emoções, fantasias, estados de humor, visões, sonhos; sua linguagem é imagética, metafórica, simbólica, alegórica, visto que ela é "a mãe de todas as possibilidades":

Alma é o que vive no homem, aquilo que vive por si só gera vida; por isso Deus insuflou em Adão um sopro vivo a fim de que ele tivesse vida. Com sua astúcia e seu jogo de ilusões a alma seduz para a vida a inércia da matéria que não quer viver. Ela (a alma) convence-nos de coisas inacreditáveis para que a vida seja vivida. A alma é cheia de ciladas e armadilhas para que o homem tombe, caia por terra, nela se emaranhe e fique preso, para que a vida seja vivida. [...] ter alma é a ousadia da vida, pois a alma é um daimon doador de vida, que conduz seu jogo élfico sobre e sob a existência humana (JUNG, 2000, p. 36).

A anima, personificação de todas as tendências psicológicas femininas na psique do homem, é alma, personalidade interior, disposição íntima dos indivíduos. A alma é anima, arquétipo da vida que resulta do instinto, assim diferenciando-se do "apenas natural" (natureza biológica), de modo que ela tanto é abstração, reflexão, quanto ritmo da vida, ondulações, imaginação. Quando a alma irrompe (isto é, quando se manifesta de forma consciente), ativase a capacidade interna, acendem-se a luz e o fogo vital que faz emanar da matéria bruta a razão e o espírito, manifestando-se, assim, a realidade metafísica. Portanto, insights, percepção profunda e emoção ampliam a hipóstase da alma.

De acordo com Jung (2000, p. 207), alma não é espírito. Espírito é algo puro que vem de cima, proporcionando leveza, flutuação, libertação do mundo ctônico, sobrevoo, estado de graça, constituição sutil: "Quando algo de psíquico ocorre no indivíduo e este sente que o fenômeno lhe pertence, trata-se de seu próprio espírito" que se manifesta como um fenômeno psíquico espontâneo. Alma, (“na forma gótica grega saiwalô, significa 'movente', 'iridescente"') é "semelhante a uma borboleta, que inebriada, passa de flor em flor e vive de mel e de amor". Sua voz élfica, escondida por trás da consciência, seduz para a vida através de um jogo de ilusões.

Veículo de transformação, por excelência, a anima é o arquétipo mobilizador da vida que estimula os homens a todo tipo de aventura da alma, para a ação e para a criação. A anima leva o indivíduo para o mundo divino, onde tudo se torna numinoso. Conservador, esse 
arquétipo prende-se à humanidade mais antiga de um modo exasperante, podendo "aparecer como anjo e como luz, como psicopompo, para conduzir até o significado mais alto" (JUNG, 2000, p. 36).

Jung relaciona a anima com o princípio erótico, o que implica comprometimento passional. Sapiência, grandeza, devoção, romantismo estético, relacionamento amoroso mítico e místico são personalidades que resultam dos estágios da anima/Eros que se evidenciam em poetas orientados pela energia anímica. Seduzidos pela divindade, pela beleza, pela perfeição, não raro, eles sublimam o desejo masculino e idealizam o ser feminino através do amor casto, como o que se expressa na imagem da esposa do Cântico dos Cânticos e em tantos poemas místicos que falam do amor esponsal de Deus. A anima é uma energia vital que envolve e convence a alma à aventura por mundos desconhecidos. Com a anima entramos

no reino dos deuses, ou seja, na área que a metafísica reservou para si. Tudo que é tocado pela anima torna-se numinoso, isto é, incondicional, perigoso, tabu, mágico. Ela é a serpente do paraíso do ser humano inofensivo, cheio de bons propósitos e intenções. [...] Conservador, esse arquétipo prende-se à humanidade mais antiga de um modo exasperante; podendo aparecer como anjo e como luz, como psicopompo, e conduzir até o significado mais alto. [...] A anima é energia vital, fogo, luz suprema (JUNG, 2000, p. 37).

No poema Noche oscura, o Eros transcendentalizado atrai a alma poética sedenta de amor ao templo do coração para viver na carne a transubstancialização do desejo por Deus. Para além de um evento psíquico, o poema revela uma hipóstase do belo e do sublime como uma epifania do Amor.

\section{A noite escura da alma}

En una noche oscura,

Con ansias, en amores inflamada,

¡oh dichosa ventura!,

Sali sin ser notada,

Estando ya mi casa sosegada. 
Em uma noite escura, a alma ansiosa, ardendo de amor, sai de sua casa sossegada sem ser vista. A que noite se refere o ser poético? Apenas ao tempo cronológico ou a um tempo simbólico de sacrifício?

Jung (1987, p. 525-527) fala da "noite escura da alma" como uma das etapas da jornada psicológica, denominada de processo de individuação ou crescimento espiritual, em que a pessoa desce "às camadas mais profundas do inconsciente, um lugar sombrio em que são superadas obscuras resistências e forças esquecidas, perdidas, são revitalizadas" a fim de que se tornem disponíveis para a tarefa de autotransformação. Em determinadas fases da vida, certos indivíduos se sentem motivados a buscar um sentido para sua vida material ou espiritual através de uma revisão dos erros e, a partir deles, encontrar o caminho da realização pessoal. Tal processo, que pode ser orientado por um psicólogo ou por um diretor espiritual quando se trata de uma experiência mística, realiza-se sempre como um ato consciente da vontade.

Este é o trajeto da individuação, processo através do qual o indivíduo empreende uma viagem simbólica em direção ao centro da psique para operar mudanças psicológicas e renovação da vida pessoal, distinguindo a psicologia geral e coletiva da particular e individual, ou seja, a pessoa torna-se independente da opinião dos outros. A meta da individuação consiste em destituir o Si-mesmo dos falsos envoltórios da Persona e da força sugestiva das imagens primordiais. Jung (1995, p. 345) diz que esse processo de transformação pessoal tem início quando o caminho existencial muda seu itinerário da euforia dos sentidos para a expectativa da morte ou para a transformação espiritual. No processo de individuação, cabe ao ego trazer à luz da consciência o deus imanente vital para "salvar a alma perdida".

Emma Jung (1991, p. 69) refere-se a esse tema da salvação da alma como libertação das forças instintuais inconscientes, que consiste no reconhecimento e integração à consciência do lado primitivo interior que permaneceu indiferenciado na psique humana durante $o$ desenvolvimento da consciência, sendo necessário reintegrá-lo ao ego para promover a harmonia consigo, com o outro e com o mundo.

A noite escura da alma proporciona o encontro com a Sombra. Em termos junguianos, a Sombra representa qualidades e atributos desconhecidos ou pouco conhecidos do ego; o nome sugere "escuridão", faz pensar naqueles conteúdos privados da luz da consciência, "o lado obscuro, ameaçador e indesejado da nossa personalidade" (SANFORD, 1988, p. 64), é um dos arquétipos que mais influenciam o ego porque, algum dia, seu conteúdo já pertenceu à 
consciência, por isso, ao negligenciá-la, o ego sente-se em débito e guarda um profundo sentimento de culpa.

Comumente, nas representações coletivas e projeções pessoais, este arquétipo é identificado com o demônio, o arqui-inimigo de Deus. As serpentes, os vermes e as aranhas personificam os conteúdos da Sombra porque habitam as trevas noturnas ou se escondem nos mistérios insondáveis. Quando se enfrenta a Sombra, um Eu primitivo rejeitado irrompe como um apelo do inconsciente para o prazer da carne, tudo aquilo que é demoníaco no homem se evidencia: crimes, engodos, mentiras, trapaças. Surgem na consciência o aproveitador, o falsário, o invejoso, o solitário, o impotente, o sofredor, o derrotista, o ciumento.

O processo de individuação permite que o indivíduo se olhe no espelho. Do ponto de vista psicológico, olhar-se no espelho significa retirar a máscara, conscientizar-se da Sombra, atitude que requer esforço moral e muita bravura para a alma que está no labirinto da noite escura, pois, consoante Jung (2000, p. 30), o espelho não lisonjeia, mostra a face verdadeira que está por trás da máscara. Interpretada sob o prisma psicológico, a metáfora do espelho reitera a metáfora do porão e do fosso que conotam lugar inferior escuro e fétido onde a consciência se depara com os erros e defeitos monstruosos que habitam o inconsciente e irrompem com a Sombra.

Para von Franz (In: JUNG, s.d., p. 170), o porão, "subsolo da psique” com portas sem chave, é o mundo subterrâneo e escuro, com elementos bizarros que simbolizam o inconsciente e se abre às influências da Sombra. Esse confronto com o lado escuro da psique é a primeira e mais importante etapa do processo de individuação porque favorece a integração dos complexos, a retirada das projeções e a restituição da energia necessária ao desnudamento do ego, uma vez que é nesse lado escuro que estão os instrumentos fundamentais para o aprimoramento da personalidade, possibilitando à pessoa perceber seus erros, corrigi-los e crescer com eles.

Envolta pela escuridão da noite, a alma segue pelos tortuosos e obscuros caminhos da consciência, um caminho da negação dos prazeres carnais e mundanos. "No vocabulário dos místicos, esse é o estágio do Caminho, da purificação do eu", em que os sentidos são humilhados e as energias e interesses estarão concentrados em coisas transcendentais. Trata-se do "processo de dissolução, transcendência ou transmutação das imagens do passado pessoal" com indicações daquilo que o iniciado deve fazer para olvidar o mundo da matéria (CAMPBELL, 2000, p. 105). Do ponto de vista mítico, "noite escura da alma” ou nekyia (termo 
grego que significa descida ao "país dos mortos"), significa descer ao mundo inferior, um lugar onde o "peregrino do caminho" se despe de todas as vaidades e se purifica das imperfeições e dos defeitos. No conhecimento dos místicos, estas provações são experimentadas como fase de iluminação. Enfrentar a Sombra significa fazer um exame de consciência para trazer à luz imperfeições da alma e erros cometidos.

Portanto iluminar a consciência é o sentido da metafórica "noite escura da alma", cuja experiência deixa um aprendizado de como é necessário se tornar cativo das "trevas subterrâneas da psique" para acender a lâmpada do conhecimento sélfico no mundo solar da consciência. Este é o possível sentido simbólico principal da "noite escura" no poema. A alma vai se purificando no caminho espiritual, vai despindo os "véus" sujos do ego, vai revelando a Sombra, vai abandonando os condicionamentos temporais e profanos da morada corporal para que o espírito possa encontrar Deus. O desnudamento simbólico da alma-amante corresponde à busca de perfeição, uma vez que a entrada no Jardim das "açucenas" requer o abandono dos "véus ilusórios" das aparências do ego e a entrega total e exclusiva da alma ao Amado. O poema reescreve na noite escura os passos sacrificiais no labirinto em cujo centro, no coração, o grande Mistério do Amor espera em silêncio.

O lugar da passagem pela "noite escura da alma" também é representado pela cabana do eremita, um espaço de reclusão e contemplação que, segundo Bachelard (1993, p. 76) guarda reminiscências de um passado paradisíaco "Imemorial" onde surgem imagens primitivas do refúgio e do aconchego que tanto atraem um "sonhador" (o idealista) em seus "devaneios", com seus sentimentos nobres das bem-aventuranças. "Iluminada por uma lâmpada, a cabana do eremita significa o olho humano aberto para a noite" que credencia a introspecção e a solidão contemplativas; um olho que vigia sozinho diante de Deus, enquanto a alma segue seu caminho de provas.

No recolhimento, em sua casa sossegada, a alma viveu essa "dichosa ventura" "en la noche dichosa" sin otra luz y guia/ sino la que en el corazón ardía". A noite iluminada pela lâmpada da consciência vigilante do amor ao divino alimenta o desejo de fugir do mundo material ilusório e impiedoso. "En la noche dichosa,/ en secreto, que nadie me veía, Ini yo miraba cosa/ oscuras y segura/ por la secreta escala, disfrazada”, a alma incendiada de amor reservou-se à reflexão no segredo do seu coração para, ao retornar de seu recolhimento interior, melhor desfrutar do encontro com o seu bem Amado, pois, conforme Bachelard (1993, p. 111), "os regressos humanos acontecem de acordo com o grande ritmo da vida, ritmo que atravessa 
os anos, que luta pelo sonho contra todas as ausências". A noite escura torna-se, assim, um cativeiro oculto pelas sombras silenciosas e harmônicas no caminho da vida consagrada, que leva a profundas abstrações e promove o meio necessário para a peregrinação em busca do divino.

\section{A função do labirinto na "noite escura da alma"}

A origem do labirinto é mítica; nasceu no imaginário grego. Trata-se de uma construção arquitetônica elaborada pelo engenho de Dédalo no palácio cretense de Minos com a finalidade de aprisionar o Minotauro, um monstro antropófago - homem com cabeça de touro - nascido do adultério de uma rainha com um deus. Semelhante à teia de aranha, conforme explica Chevalier (1997, p. 530), esta construção se define como "um entrecruzamento de caminhos dos quais nenhum tem saída e constituem assim impasses; no périplo pelo labirinto é mister descobrir a rota que conduz ao centro", em cujo espaço algo ou alguém de significativa importância é guardado.

O herói Teseu entrou no labirinto para matar o Minotauro, mas só conseguiu sair de lá graças à ajuda da princesa Ariadne que lhe deu um fio através do qual ele se norteou no périplo de retorno. O mito do Minotauro permaneceu no imaginário coletivo, enquanto a arquitetura do labirinto foi utilizada como forma de defesa nos portões das cidades, nos palácios, nos locais sagrados, e tornou-se símbolo de lugar onde se guarda um tesouro, cujo acesso só é permitido aos que conhecem, de forma própria, os seus planos arquitetônicos.

No centro do labirinto mítico/simbólico há sempre algo secreto, poderoso, precioso e sagrado destinado a um virtuose que deverá se submeter a provas de iniciação que requisitam destreza, disciplina, renúncia, paciência e perseverança.

O labirinto também conduz o homem ao interior de si mesmo, a uma espécie de santuário interior e escondido, no qual reside o mais misterioso da pessoa humana. Pensa-se aqui em mens, templo do Espírito Santo na alma em estado de graça, ou ainda nas profundezas do inconsciente. Um e outro só podem ser atingidos pela consciência depois de longos desvios ou de uma intensa concentração, até esta intuição final em que tudo se simplifica por uma espécie de iluminação. É ali, nesta cripta, que se reencontra a unidade perdida do ser, que se dispersara na multidão dos desejos (CHEVALIER, 1997, p. 531). 
O lugar simbólico da aventura mítica/mística/psicológica é sempre uma região desconhecida, cheia de perigos, habitada por seres estranhos, "uma terra distante, uma floresta, um reino subterrâneo, a parte inferior das ondas, a parte superior do céu, uma ilha secreta, o topo de uma elevada montanha ou um profundo estado onírico" (CAMPBELL, 2000, p. 66). Nessa fatídica região de tormentos inimagináveis, o peregrino do caminho pode viver façanhas sobre-humanas. Jung (2000, p. 31) o compara a "um desfiladeiro, um portal estreito, cuja dolorosa exiguidade não poupa quem quer que desça ao poço profundo”. Entretanto, essa é via necessária para quem deseja encontrar-se com o seu lado oculto no fosso do inconsciente a fim de galgar novo estágio de conscientização.

Campbell escreve que o difícil caminho mítico das provas está repleto de imagens simbólicas do labirinto. O labirinto psicológico é representado por uma paisagem noturna, povoada por entes perigosos que perseguem e tentam interceptar o percurso da alma:

E assim é que se alguém - em qualquer lugar da sociedade - assumir por si mesmo a tarefa de fazer a perigosa jornada na escuridão, por meio da descida, intencional ou involuntária, aos tortuosos caminhos de seu próprio labirinto espiritual, logo se verá numa paisagem de figuras simbólicas (podendo qualquer delas devorá-lo) [...]. Trata-se do processo de dissolução, transcendência ou transmutação das imagens infantis do nosso passado pessoal (CAMPBELL, 2000, p. 105).

Campbell (2000, p. 28) explica que os "peregrinos do caminho" vivem de muitas maneiras essa jornada arquetípica por vias labirínticas e são salvos das dificuldades de suas buscas pelos auxílios simbólicos nos rituais de passagem dos quais recebem os sacramentos geradores de graça.

A transformação do eu, que se opera no centro do labirinto e que se afirmará à luz do dia no fim da viagem de retorno, no término dessa passagem das trevas à luz, marcará a vitória do espiritual sobre o material e, ao mesmo tempo, do eterno sobre o perecível, da inteligência sobre o instinto (CHEVALIER, 1997, p. 532).

O labirinto corresponde ao "Tememos", o lugar sagrado onde eram celebrados os mistérios de renascimento do homem. Psicologicamente, significa o inconsciente através de cuja via a alma penitente caminha, longe da influência do mundo exterior. O recolhimento nesse local corresponde à entrada do fiel no templo, onde o iniciado é revivificado pela lembrança de 
que é pó e cinzas. O interior do templo é a terra celeste, além e acima, destinado ao desnudamento do ego. O "templo do renascimento" está no centro do labirinto, onde habita o Incriado-Imperecível. Os mitos mostram que os homens percorrem esse caminho para buscar a explicação dos mistérios da vida e da morte.

\section{O arauto e o guia da alma na "noite escura"}

Conforme Campbell (2000, p. 60-62), o chamado à aventura mítica de transformação da vida é uma mensagem desconhecida da consciência que pode surgir espontaneamente na psique, mas que, apesar de assustador para a personalidade consciente, é, de alguma forma, familiar ao inconsciente. Tal mensagem anuncia, por meio de imagens mentais, que há um erro a reparar. "Forças psicológicas podem surgir para dizer que chegou o tempo de repensar e reorientar as soluções dos problemas existenciais a fim de construir uma nova forma de viver. O erro, resultado de desejos e conflitos reprimidos que o sujeito carrega dentro de si e pode equivaler ao "ato inicial do destino", "são ondulações na superfície da vida, produzidas por nascentes inesperadas, tão profundas quanto a própria alma”. O chamado pode ser também uma convocação para a fase da iluminação entendida como o despertar do eu para a transformação interior.

Do ponto de vista junguiano, isto equivale à harmonização do consciente com o nosso centro interior, o Self, e compreende um processo de conscientização de algo que deve ser mudado ou corrigido na forma de viver, de agir ou de pensar, que começa com grande sofrimento e renúncia. Essa mudança, conforme Campbell (2000, p. 60) é um ato de "coragem para descerrar as cortinas de um mistério de transfiguração" para quem deseja ou precisa ultrapassar certos horizontes sociais e reformular velhos padrões emocionais e comportamentais.

O chamado para o crescimento psico-espiritual é feito pelo Self, o arquétipo guia da individuação, também denominado de "grande-homem" ou homem-divino, que se situa no centro mais profundo da psique. A bem dizer, o Self é o centro reintegrador das energias desordenadas do inconsciente e da consciência. Jung (1988, p. 28-29) explica que o alvo da individuação é um relacionamento harmonioso com Self, que pode ser representado por figuras humanas superiores ou entidades espirituais. Ele tanto funciona como a meta quanto como arauto e guia da jornada da alma, dando os sinais orientadores das transformações que devem 
ser operadas no ego. Seu papel equivale, precisamente, ao do psicopompo, que auxilia nas provas do caminho. É ele quem põe o bálsamo curativo nas feridas do trajeto. O Self orienta a renovação espiritual que exige do ego o sacrifício de afastar-se do mundo, criando uma situação interna no sujeito que possa avançar para novas etapas de conscientização, unificação e integração da personalidade a fim de assumir as responsabilidades da vida interior e enfrentar a realidade exterior de modo transformado. No modelo progressivo da individuação, o Self, que representa a totalidade centralizada no núcleo do labirinto da psique, aparece no momentochave de transformação da vida, quando se integra a Sizígia.

$\mathrm{Na}$ óptica dos místicos cristãos, a alma pode ouvir o chamado de Deus por meio de uma graça concedida pelo próprio Deus, que lhe fala através da voz interior, entendida como um desejo incontrolável de amar e se unir ao Amor. Essa vontade da alma já é condição prévia para enfrentar os estágios de purificação no templo sagrado do coração.

No poema Noche oscura, o Amado chama a alma e ela conhece a sua voz, sabe onde ele está e o segue guiada pela luz do meio-dia: Sin otra luz y guial Sino la que en el corazón ardíal Aquesta me guiabal Más cierto que la luz del mediodial Adonde me esperabal Quien yo bien me sabía,/ En parte donde nadie parecía. A luz do meio-dia é um símbolo epifânico da presença do Espírito que ajuda a alma a sair na noite escura, iluminando-a com a luz da consciência. A matéria frágil, que definhava nas trevas da alma culpada, ascende transformada para o Reino do animus/Espírito. O Self e o animus espiritual estão metaforizados como luz: "sin otra luz y guia/ sino la que en el corazón ardía"; e como vento: "Y el ventalle de cedros aire dava. El aire del amena, Cuando sus cabellos esparcía". O vento representa a abstração, vivacidade, leveza, fluidez e mobilidade do espírito, sentido pela alma no estado deleitoso do encontro com o Amado. Para a alma que transcendentaliza, o Espírito é luz do meio-dia que auxilia o bem sucedido esforço de ascensão no encontro para o qual se preparou.

Muitos símbolos representam o animus/Espírito; cada um deles se expressa conforme a função que exerce no inconsciente. Jung (1998, p. 290) explica que os nomes latinos animus, "espírito", e anima, "alma", têm o mesmo significado do grego anemos, "vento". A outra palavra grega que designa "vento", pneuma, significa também espírito. A palavra grega psyché tem um parentesco muito próximo com esses termos e está ligada a psycho, "soprar", a psychos, "fresco", a psychros, "frio", e a physa, "fole". A gradação etimológica mostra que a palavra "alma", no grego, denota a ideia de "ar em movimento", de "sopro frio do espírito". Talvez por isto, separada do corpo, o inconsciente coletivo conserva e ideia mítica de que a alma é um 
corpo frio, etéreo e invisível. Incorpora-se à vitalidade erótica e à beleza da natureza a brisa e a viração, que pode sugerir o animus, elemento masculino interno, o princípio luminoso do logos que está contido na imagem do Amado.

\section{O hierosgamos}

A partir da quinta estrofe até o final do poema dá-se a apoteose, o casamento sagrado da alma peregrina com seu amado divino, motivo pelo qual a voz poética rejubila: “;Oh noche, dichosa"/ "amable más que el alborada!/ ;Oh noche, que guiaste!;Oh noche que juntastel Amado con amada,/ Amada en el Amado transformada!

Do ponto de vista mítico, este é o encontro com a deusa ou o deus, que aparece para trazer força para o mortal no difícil caminho das provas e abençoá-lo, significando que sua jornada de busca ou de transformação foi aprovada pela divindade.

O deus ou a deusa é um arquétipo, modelo de perfeição, representado(a) por qualquer figura no plano material que metaforiza a morte de tudo o que morre ou a vida de tudo o que vive. Este arquétipo influencia todas as etapas da existência - do nascimento à morte -, representando as formas do sagrado em termos universais e pessoais. Por intermédio do encontro com o deus ou a deusa, a alma é liberta das forças imperativas dos sentidos inadequados e a mente abre-se à presença inescrutável do Ser superior. Campbell escreve que, nos mitos, esta figura surge em momentos de crise quando o herói imerge nas trevas da "câmara mais profunda do coração":

Tem havido, em numerosas tradições religiosas, uma utilização pedagógica, conscientemente controlada, dessa imagem arquetípica, para fins de purgação, estabilização e iniciação da mente na natureza do mundo visível. Essa imagem divina é também uma visão religiosa que anima a alma penalizada pelos terrores inconscientes, afastando-a de todas as "delusões", não apenas por meio de reajustamento do desejo erótico de viver (Eros) e da hostilidade à vida (Thanatos) - que apenas geraria um novo contexto delusório -, mas por meio da extinção desses impulsos em suas próprias raízes (CAMPBELL, 2000, p. 115).

O deus ou a deusa mítica é uma das mais fascinantes e atrativas representações do poder transcendente caracterizado pela beleza, claridade, pureza, harmonização de todos os pares de opostos, que combina prodigiosamente a comunhão da imortalidade com a transitoriedade da 
matéria, em outras palavras, a comunhão do homem com um deus. Na opinião de Campbell (2000, p. 169), o deus ou a deusa transporta a mente e o espírito, não acima, mas através dele/dela para o prodigioso vazio onde a alma pode, finalmente, ser transfigurada.

Aureolada de luz, a alma transformada é guiada pela imago dei, o auxiliar no caminho espiritual e o objeto da busca sagrada no poema. Extinto o fogo tríplice do desejo, da hostilidade e da ilusão, triunfante, ela se entrega à totalidade do Eros espiritual que a transporta para o sublime auge da ventura de seu hierosgamos.

No processo de individuação ou crescimento psicológico, o hierosgamos mítico é denominado de Sizígia - coniunctio - onde acontece, no centro mais profundo da psique, o encontro dos opostos animus e anima, consciência e inconsciente, que conclui o processo de individuação bem sucedido. Em outras palavras: A alma cativa, impulsionada pelo Self, libertase das projeções da Sombra e alcança o Si-mesmo - o próprio Self - onde acontece, simbolicamente, o casamento interior, que resolve os dramas existenciais das necessárias mudanças de vida.

No poema Noche oscura, a alma mística busca Deus e O encontra, com Ele ata sua vida e experimenta as delícias do Amor erótico transcendental, permanecendo encastelada no reino de Eros, absolutamente transfigurada pela presença viva do Amado que lhe proporciona êxtase e encantamento. No reino do Amado divino, onde o grande mistério transcende a bruta matéria, a alma canta sua eterna alegria, ainda que esteja ligada à matéria porque está unida a Deus é permanecer para sempre no Jardim das delícias supremas: "En mi pecho florido,/ Que enterro para él solo se guardaba,/ Allí quedó dormindo,/ Y yo le regalaba,/ Y el ventalle de cedros aire dava./ El aire del amena,/ Cuando sus cabellos esparcía,/ Con su mano serenal En mi cuello hería,/ Y todos mis sentidos suspendia." No mundo simbólico do Self, a anima Sophia e o Eros transcendentalizado podem levar a alma ao reino divino.

A alma plenificada conclui seu canto: "Quedéme y olvidéme,/ El rostro recline sobre el Amado;/ Cesó todo, y dexéme,/ Dexando mi cuidado/ Entre las azucenas olvidado.” O vento anímico que sopra no "leque dos cedros" simboliza a presença festiva do Espírito que festeja o enlace sagrado e a infinita e fiel aliança nupcial. As açucenas que, numa camada muito profunda do pensamento primitivo, estão associadas às virtudes sagradas do renascimento espiritual, mantendo uma ligação com a fonte inesgotável que sustenta a vida cósmica, simbolizam a anima Sophia. Numa perspectiva mística, até bíblica, a alma poética conhece a Essência e restabelece o elo original perdido com o Uno. A alma, anima, Psiqué, comunga com Deus, o 
Self divino em profundo estado de êxtase amoroso, numa espécie de deslumbramento erótico alimentado pelo sopro do animus Espírito.

\section{Enfim...}

Os filósofos gregos disseram que o acesso à divindade é alcançado pela razão associada a certo grau de ascetismo, o que significa livrar-se do "peso da carne" para ascender à imagem do Bem, do Belo e do Verdadeiro. Platão pensava que só se chega a Deus pelo caminho da contemplação intelectual, da contemplação metafísica marcada pela dialética.

Contrariamente, os místicos sempre souberam que se chega a Deus não somente pela via intellectionis, mas pelo difícil caminho do Amor. A palavra mística (que está relacionada com o termo mysterion) significa mistério, espaço-ideia onde Deus se esconde para atrair e conduzir a alma inebriada pelo amor a Si. Deus é alcançado pela via amoris. Ele, que é puro Espírito e puro Amor, seduz a alma perfeita, isto é, sem mancha de pecado, e provoca nela o desejo de se unir a Ele numa comunhão perfeita e infinita no Paraíso espiritual onde liberdade e graça se complementam, o espírito se eleva, a beleza se substantiva e a oração e o êxtase laudatório se amalgamam num todo único e inseparável.

Este é o sentido que perpassa o poema lírico Noche oscura, de São João da Cruz, cuja poética humano/divina conduz tão bem o tema do amor erótico na união mística e funde num todo único três realidades inefáveis: Deus, Amor e Poesia. Este poema evoca, de forma metafórica e simbólica, a via sacrificial por que passa a alma na subjetividade de um eu poético lírico em busca de Deus, enfatizando, na metáfora do idílio amoroso, a alegria da salvação da alma por ocasião da celebração anímico-espiritual do Amor eterno. A beleza poética chega ao ápice na ambiguidade dos esponsais quando as imagens do amor erótico são transcendentalizadas, perpetuando a presença de Deus na excelência do Amor que une miséria humana e misericórdia divina.

Uma teofania provoca medo, espanto, êxtase, encanto e uma profunda transformação interior, pois Deus é um mysterium tremendum et fascinans que se oculta na matéria espiritual, seduzindo a alma para um estado de perfeita harmonia com Ele e consigo. Deus é o fascinante aspecto do mirum que pode encher a alma e lhe dar a paz indescritível. Sua presença emudece qualquer mortal e pode conduzir a estranhas excitações e alucinações. Isto porque uma teofania desperta o sentimento de que o numinoso é tudo e a criatura é nada. Tal temor tem um 
significado muito mais complexo porque Deus é majestas, que desperta reconhecimento e reverência, e é orgé, a energia que leva o homem a contemplá-Lo numa obediente entrega de seu ser total. Com efeito, a revelação de Deus é estranha à carne perecível por causa da insignificância da criatura diante da grandeza, da beleza e do poder majestoso e absoluto do Criador.

Porém os místicos sempre creram que por trás das aparências do mundo material, num estado-lugar inimaginável reina o Sumo Bem, cuja natureza foge à compreensão humana. Substância inefável, imperceptível e invisível, até para os olhos mais crédulos, este Ser magnânimo é abstraído como o Belo Amor. Isto ainda é um grande mistério para a mente materialista, não para a alma poética que com Ele se uniu e nEle repousou.

Não seria esta a experiência “erótica” dos místicos? O místico é sempre um enamorado de Deus. O eu poético lírico que fala no poema Noche oscura é lírico, mítico e místico, isto aumenta a carga emocional da metáfora que sugere a convivência "real" desse eu que sofreu as exigências do Amor na solidão, na renúncia, na negação dos sentidos durante sua passagem pela labiríntica noite escura da consciência e experimentou o Amor perfeito. Mas a alma, que se apropria de outros patamares da existência, festeja a noite escura que a tornou capaz de estar com o seu único Bem. Deixando o casulo do si-mesmo autocentrado e egoísta, ela é redimida no Amado, fonte de Vida. A relação alma-Deus, Amado-amada se completa no casamento sagrado.

A narrativa do mito de Eros e Psiqué conclui com um gran finale romântico: Eros desceu à terra, amou Psiqué, por ela foi amado, desposou-a depois do sofrimento da ausência, libertoua do sono da morte, subiu com ela para o Olimpo, divinizou-a e permaneceram fiéis eternamente. Não foi menor e menos feliz o final da busca da alma em Noche oscura. O Deus oculto manifesta-se de forma humana e a arrebata do cárcere de sua limitação. Se perguntarmos ao ser poético sobre a face dessa divindade de quem tão somente percebemos alguns véus, ele responderá que pulsa viva dentro do coração a chamar a eleita para o êxtase do Amor.

\section{NOITE ESCURA}


que é a união com Deus,

pelo caminho da negação espiritual

Em uma noite escura,

Com ânsias, em amores inflamada,

Oh ditosa ventura!,

saí sem ser notada,

Estando já minha casa sossegada.

Às escuras e segura,

pela secreta escada, disfarçada,

oh ditosa ventura!

às escuras e encoberta,

estando já minha casa sossegada.

Na noite ditosa,

em segredo, que ninguém me via,

nem eu nada olhava,

sem outra luz e guia

senão a que no coração ardia.

Só esta me guiava

Mais certa que a luz do meio-dia

onde me esperava

quem eu bem sabia,

em lugar onde ninguém aparecia.

Oh noite, que guiaste!

Oh noite, amável mais que a alvorada!

Oh noite que juntaste

Amado com amada,

Amada no Amado transformada!

Em meu peito florido, que inteiro só para ele se guardava, 


\author{
ali adormecido, \\ e eu o afagava, \\ E o leque de cedros brisa soprava.
A viração amena,
quando seus cabelos espargia,
com sua mão serena
o meu colo feria,

E todos os meus sentidos suspendia.

\author{
Fiquei desfalecida, \\ o rosto reclinei sobre o Amado; \\ cessou tudo, e me entreguei, \\ deixando o meu cuidado \\ Entre as açucenas esquecido.
}

(Tradução nossa)

\title{
Referência
}

BACHELARD, Gaston. A poética do espaço. Tradução de Pádua Danesi. São Paulo: Martins Fontes, 1993.

CAMPBELL, Joseph. O herói de mil faces. Tradução de Adail Ubirajara Sobral. São Paulo: Pensamento, 2000.

CATECISMO DA IGRAJA CATÓLICA. São Paulo: Edições Loyola, 1999.

CHEVALIER, Jean. GHEERBRANT, Alain. Dicionário de símbolos. Tradução de Vera da Costa e Silva et al. 11. ed. Rio de Janeiro: José Olympio, 1997.

CRUZ, São João da. Poesias completas. Lisboa: Assírio e Alvin, 1989.

HARDING, Mary Esther. Os mistérios da mulher. Tradução de Maria Elci Spaccaquerche Barbosa e Vilma Hissako Tanaka. 3. ed. São Paulo: Paulus, 1985.

JUNG, Carl Gustav. Os arquétipos e o inconsciente coletivo. Tradução Maria Luiza Appy e Dora Mariana R. Ferreira da Silva. Petrópolis: Vozes, 2000. 
JUNG, Carl Gustav. A natureza da psique. Tradução de Dom Mateus Ramalho Rocha. 4. ed. Petrópolis: Vozes, 1998.

JUNG, Carl Gustav. Símbolos de transformação. Tradução de Eva Stern. 3. ed. Petrópolis: Vozes, 1995.

JUNG, Carl Gustav. O espírito da arte e na ciência. Tradução Maria de Morais Barros. 3. ed. Petrópolis: Vozes, 1991.

JUNG, Carl Gustav. Aion. Tradução Pe. Mateus Ramalho Rocha. 2. ed. Petrópolis: Vozes, 1988.

JUNG, Carl Gustav. Tipos psicológicos. Tradução de Álvaro Cabral. 4. ed. Rio de Janeiro: Guanabara Koogan, 1987.

JUNG, Carl Gustav (org.). O homem e seus símbolos. Tradução de Maria Lúcia Pinho. Rio de Janeiro: Nova Fronteira, s.d.

JUNG, Emma. Animus e Anima. Tradução de Dante Pignatari. São Paulo: Cultrix, 1991.

PLATÃO. A República. São Paulo: Martin Claret, 2000.

PLATÃO. O Banquete. Tradução de Manuel de Oliveira Pulquério, Maria Teresa Schiappa de Azevedo e José Ribeiro Ferreira. Lisboa; São Paulo: Verbo, 1973.

SANFORD, J. Mal: o lado sombrio da realidade. Tradução de Sílvio José Pilon e João Silvério Trevisan. 2. ed. São Paulo: Paulinas, 1988. (Coleção amor e Psique).

Artigo recebido em: 17.10.2019

Artigo aceito para publicar em: 02.12.2019 